\title{
KRONIK
}

\section{Indflydelse på teknologi forudsætter kvalificeret fantasi}

\author{
Sidsel Lond Grosen
}

At teknologiske forandringer har betydning for arbejdet - dets betingelser og indhold samt de ansattes oplevelse af arbejdets formål og mening - er ikke til at komme udenom (se fx Badham, 2005; Grosen et al., 2021 under udgivelse). Samtidig er teknologi dog ret upolitiseret med hensyn til ansattes indflydelse på arbejdspladsernes valg og anvendelse af teknologier. Hvis der for alvor skal gøres noget ved dét, er det dog ikke nok at kræve, at de ansatte bliver hørt. Det er også nødvendigt at klæde de ansatte på til at kunne tage reel indflydelse, der kan gøre en forskel og som med inddragelse af de ansattes viden om arbejdets udførelse kan kvalificere valg og anvendelse af teknologi. Jeg vil i denne kronik diskutere, hvad det kræver af de ansatte at tage en sådan indflydelse på arbejdspladsernes teknologi. Det vil jeg gøre ved at argumentere for, at dét, man kan kalde kvalificeret fantasi, er en forudsætning for reel indflydelse. For at kunne forholde sig til hvilken teknologi og teknologianvendelse, der er hensigtsmæssig, må man nemlig være i stand til at forestille sig fremtiden med en teknologi - forestille sig hvad teknologien vil betyde for måden, det daglige arbejder former sig, for hvordan teknologien vil gribe ind i den måde, man tænker og udfører arbejdet og for den måde, man relaterer til kolleger, ledelse, borgere, kunder, elever etc. Det drejer sig altså ikke om hvilken som helst fantasifuld fabuleren, men om fantasi kvalificeret af erfaring med arbejdet.

\section{Fantasi og indflydelse}

At bygge et argument om indflydelse og demokrati på fantasi kan ved første øjekast synes en smule luftigt. Fantasi og forestillingsevne har dog spillet en central rolle på tværs af forskellige veletablerede akademiske traditioner, der beskæftiger sig med demokrati og med at kunne forstå samfundsudviklingen. Jeg vil her dykke ned i forskellige perspektiver som afsæt for at få øje på og undersøge sammenhænge mellem teknologi, fantasi og medarbejderindflydelse. I kritisk teori, ikke mindst den del der relaterer til Negt, spiller social fantasi - dét at forestille sig en anden fremtid end den umiddelbart foreliggende en uomgængelig rolle $\mathrm{i}$ forhold til at træde i karakter som demokratiske mennesker og tage ansvar for fremtiden (Negt, 2019; Olsén et al., 2003). På den anden side af Atlanten har C. Wright Mills fremhævet 'sociological imagination' - at kunne forestille sig variation i menneskelige samfundsformer og liv - som grundlag for at kunne forstå sammenhænge mellem bredere samfundsstrukturer og individers liv og tilgang til verden, samt for at kunne forstå og handle på samtidens 
problemer (Mills \& Gitlin, 2000, original Mills, 1959). Selv om Mills og Negt kommer fra forskellige traditioner, er de fælles om at placere fantasien centralt for forståelsen af sammenhænge mellem samfundets indretning og menneskers betingelser for og måder at leve deres liv. Dette er af Negt formuleret som "en fælles social og kulturel forståelse af verdens indretning, og af de livsperspektiver den har at byde på” (Negt, 2019, s. 180). Hos både Negt og Mills er fantasien, både som en vej til at forstå hvordan strukturer og livsvilkår hænger sammen og til at forestille sig en anden fremtid, en forudsætning for demokratisk deltagelse.

Centralt i ikke mindst den kritiske teori er en forståelse af magt som indlejret i strukturer. Endringer af disse, så der skabes rum for at alle kan komme til orde og få indflydelse på egne liv og livsvilkår, er et væsentligt mål. I denne bestræbelse har der været lagt vægt på kritisk-utopisk tænkning som et middel til emancipation og demokratisk deltagelse ved med fantasiens hjælp at blive i stand til at få øje på at strukturerne kan være anderledes, og at der kan skabes rum for indflydelse. Som sådan har den spillet ind i den skandinaviske sociotekniske tradition for ansvarlig medarbejderautonomi (Nielsen, 2001).

Også andre perspektiver tildeler fantasi en udtalt rolle i forandringer af samfundet; ikke kun når forandringer skal muliggøre empowerment, men også når politik udøves mere oppefra og ned. I bogen 'Dreamscapes of Modernity. Sociotechnical Imaginaries and the Fabrication of Power' (Jasanoff \& Kim, 2015) viser forskere fra hele verden således, hvordan policy er tæt forbundet med - for ikke at sige baseret på - fantasier. I bogens studier, såvel som i mange andre tilfælde, spiller fantasier om, hvordan teknologi kan forandre verden, en væsentlig rolle. Fantasien, forestillingerne om hvad teknologierne sætter i gang, har altså en vigtig rolle, da det er dem, og ikke teknologierne alene, der bliver afsættet for politisk handlig (Jasanoff, 2015).

\section{Fantasi og teknologi}

Teknologi - især ny teknologi - har altid både pirret og forudsat fantasi. Såvel science-fiction som udvikling af ny teknologi kan ses som båret af tanker om, at 'hvis man nu havde sådan en teknologi, så kunne man ... det ene og det andet'. Her er teknologi typisk bundet sammen med forestillinger om, at den skaber forandring; hvis ikke alene så dog i forbindelse med en særlig brug af teknologien.

Som vist ovenfor er fantasi og teknologi også forbundet uden for fiktionens verden og har betydning for policy (Jasanoff \& Kim, 2015). Fantasiens rolle spiller også en stor rolle indenfor forskning og udvikling af teknologi, eksempelvis i den tradition, der kalder sig 'participatory design'. I denne tradition fremhæves det, at dét man begiver sig af med er at designe fremtider (se fx Ehn et al., 2014; Robertson \& Simonsen, 2013). En sådan proces indeholder nødvendigvis elementer af fantasi, hvor man arbejder aktivt med at forestille sig mulige fremtider med teknologier som noget, der aktivt spiller ind i dem. Samtidig er der i participatory design en eksplicit normativ opmærksomhed på, at man designer fremtider for mennesker, og at det rummer en demokratisk forpligtelse $\mathrm{i}$ forhold til "people's rights to participate in the shaping of the worlds in which they act" (Robertson \& Simonsen, 2013, p. 4). I den forbindelse er der en lang tradition for aktivt at inddrage og samarbejde med brugere om udvikling af teknologi; en tradition der har spillet aktivt ind i udviklingen af den skandinaviske arbejdslivstradition (Nielsen, 2001).

At en given teknologi dog ikke kun åbner for én mulig fremtid - med andre ord at teknologien ikke determinerer fremtiden 
- vil de fleste nok tilslutte sig. Den brede forskningstradition, der går under betegnelsen STS (Science, Technology, Society), har udviklet en stærk og mangfoldig tradition for at demonstrere, hvordan teknologi får forskellig betydning i forskellige situationer. Wanda Orlikowski anskueliggør dette i relation til arbejdspraksis ved at vise, hvordan ét og samme IT-system både indenfor og på tværs af virksomheder bruges meget forskelligt i relation til forskellige forståelser af både arbejdsopgaven og teknologien; hun begrebsliggør det ligefrem, som at systemet bliver til forskellige 'technologies-in-practice' (Orlikowski, 2000). Udover at teknologier kan bringes i spil på meget forskellige måder og med meget forskellige konsekvenser, anskueliggøres det også, at ikke kun ny teknologi giver anledning til forandring. Ændrede praksisser omkring en teknologi giver også forandringer. Dette er ligeledes vist i en dansk kontekst med et studie, der sjovt nok omhandlede samme IT-system som Orlikowskis studie: Her forandres både den administrative sagsbehandling som arbejdsmiljøet $i$ en bankafdeling gennemgribende med en ændret brug af et IT-system (Grosen, 2009). At forandringer i relation til teknologi således ikke kun sker i relation til ny teknologi, men også i forbindelse med ændringer i brugen af eksisterende teknologi, peger på, at der er grund til løbende at inddrage ansatte (som brugere i denne kroniks kontekst vil være) i forbindelse med forandringer i teknologianvendelse. Som sådan bidrager STS med et blik for at resultater ikke alene gives af, hvordan magt og modstandsmuligheder er indlejret i strukturer, men også formes og forandres løbende i daglige (arbejds)praksisser og interaktioner.

Inddragelse af ansatte i beslutninger om en fremtid med forandringer i relation til teknologi - eller ihverttilfælde reel indflydelse - kræver, at de ansatte kan forestille sig fremtiden med nye teknologier eller nye an- vendelser af kendte teknologier. Som ovenfor kan inddragelse have et normativt demokratisk afsæt, om at alle bør have indflydelse på deres egen fremtid, også når det gælder den fremtid, som teknologi er med til at forme. Det kan også ske med det primære afsæt, at det kan være hensigtsmæssigt at få mennesker, der har erfaring med de arbejdsopgaver og -kontekster teknologien skal spille ind i, inddraget i udviklingen for at understøtte, at slutproduktet også kan bruges i den praktiske arbejdssammenhæng. Helst på en måde, der spiller sammen med de ansattes forståelse af godt arbejde - forstået både som kvalitet $\mathrm{i}$ produktet og som gode arbejdsforhold.

\section{Fantasi, erfaring og teknologi}

Fantasi og erfaring står ikke nødvendigvis $i$ et nemt og uproblematisk forhold til hinanden. I den kritisk teoretiske tradition for kritisk-utopisk aktionsforskning problematiseres erfaring i den udstrækning, den animerer til vanetænkning indenfor eksisterende rammer. Der argumenteres for, at der er brug for en utopisk horisont, "fordi social fantasi indebærer et brud med eller en radikal udvidelse af det dominerende realitetsprincip" (Olsén et al., 2003, s. 192). Samtidig lægges der dog også vægt på at praksiserfaring også bidrager med indholdsmæssig kvalificering og praksisrettethed, hvorved det fremhæves at den sociale fantasi ikke må blive udvendig $\mathrm{i}$ forhold til hverdagslivets perspektiver (Olsén et al., 2003).

Praksisrettet indholdskvalificering, selv uden utopiens potentielt frisættende kvaliteter, kan der nok synes at være behov for, når der kigges ud over landskabet af studier af teknologi i arbejdslivet. Hvor den ovennævnte bog 'Dreamscapes of Modernity...' viser hvordan policy implicerer fantasier om, hvordan teknologi kan og vil forandre verden, så er det også åbenlyst at sådanne fantasier ofte ikke medtænker den praktiske hverdag hvor 
teknologierne skal bringes i spil. Inden for STS er det nærmest en selvstændig disciplin at vise, hvordan teknologi støder sammen med praksis og/eller giver nogle utilsigtede, til tider ligefrem counterproduktive, effekter (se fx Halford et al., 2010; Oudshoorn, 2008; Wilson, 2002).

Også herhjemme ser vi, hvordan politiske fantasier har betydning for menneskers arbejdsliv, men ofte også at de er meget langt fra og uden forankring i de konkrete arbejdsliv. Vi ser det fx, når der satses på digitaliseringsklar lovgivning, som samtidig skubber til faglige principper om helhedsvurdering (Justesen \& Plesner, 2018), skylle-tørretoiletter i ældreplejen, som kræver mere arbejde af både borgere og ansatte end man havde forestillet sig (Hansen \& Grosen, 2019), eller sundheds-IT der griber ind i tværfagligt samarbejde på mange planer (Andersen \& Hindhede, 2018; Bertelsen, 2007). Som disse bringes mange teknologier i spil med store forventninger til besparelser på arbejdskraft, men uden tilstrækkeligt indblik i de forandringer, der sættes i gang eller i den indsats, det kræver at få teknologien til at fungere i hverdagen.

Vi behøver ikke engang at bevæge os så langt væk som det nationale policy niveau, for at manglende indblik i det daglige arbejde skaber problemer i forbindelse med at få teknologier til at fungere i dagligdagen. Også ledelser på virksomhedsniveau - offentligt såvel som privat - handler på baggrund af teknologifantasier, som har vanskeligt ved at fungere i praksis. Det kan eksempelvis være IT-systemer, der skal give ledelsesinformation om tidspunkter med spidsbelastninger, der i stedet ender med at blive registreret i de mest rolige perioder, da det er dér, personalet har tid til at registrere (Wilson, 2002). Eller systemer der skal aflaste de ansatte gennem arbejdsdeling, men ender med at belaste ved at fjerne mening gennem opsplitning af arbejdsopgaver (Grosen, 2013).
Match mellem teknologi og arbejde, der enten 'blot' er mere arbejdskrævende at få til at passe sammen end forventet, eller som tilsigtet eller utilsigtet fjerner eller besværliggør dele af arbejdet som de ansatte finder vigtigt, belaster de ansatte kvantitativt og/eller i forhold til meningsdimensionen i arbejdet (se fx Grosen \& Hansen, 2021; Thomsen, 2016). Udover at mindske sådanne belastninger er der åbenlyse fordele for kvaliteten af både teknologi og arbejde ved at få de ansattes viden og erfaringer bragt i spil i udvikling og omlægninger af teknologianvendelsen. For at opnå disse fordele er det dog nødvendigt at viden om nye teknologier eller forandret praksis bliver sat i spil i relation til de ansattes erfaringer. Dette på en måde, så det er muligt at forestille sig, hvordan teknologier kan forandre arbejdet ned i de små detaljer, der betyder så meget i det daglige arbejde. Med andre ord, at fantasierne kvalificeres med den viden og erfaring om arbejdet, som de ansatte har.

\section{Kvalificeret fantasi og kvalificering af fantasi}

Ansatte kan naturligvis også blive grebet af mere eller mindre løsrevne fantasier om teknologiens muligheder; de er jo eksponeret for mange af de samme 'sociotechnical imaginaries' om teknologiers muligheder (og farer), fx besparelsespotentialer eller ligefrem 'disruption', som også policymakers og ledere er det. Inddragelse af ansatte gør derfor ikke nødvendigvis i sig selv, at de ovennævnte typer af problemer undgås eller mindskes.

Derfor er der brug for at inddragelse i teknologispørgsmål tages seriøst for at opnå de fordele, der kan være for alle parter. Tager vi indsigterne fra både den kritiske teori og STS seriøst kræver det etableringen af strukturer, der både understøtter indflydelse og processer, hvorigennem produkters og arbejdslivets kvalitet kan forbedres gennem inddragel- 
se af medarbejdernes kvalificerede fantasi. Strukturerne er nødvendige for at sikre, at der sker inddragelse, mens processen for at understøtte den kvalificerede fantasi og en tilbagevendende opfølgning er central for at undgå, at de ansatte blot bliver gidsler i en legitimeringsproces. Der er således brug for en indsats for at kvalificere inddragelsen af ansatte i beslutninger om teknologi i arbejdet. Der er brug for at skabe rum, hvor der arbejdes aktivt med at forestille sig hvad teknologien vil betyde for måden, det daglige arbejder former sig: Forestillingerne om hvordan teknologien vil gribe ind i den måde, man tænker og udfører arbejdet og i den måde man relaterer til hinanden med en ny teknologi eller ny måde at anvende teknologi.

Mange aktører kan bidrage til at få kvalificerede fantasier bragt i spil i forhold til ny teknologi og nye anvendelser af teknologi i arbejdet. Arbejdsmarkedets parter kan sørge

\section{LITTERATUR}

Andersen, V., \& Hindhede, A. (2018). Digitale regionale sundhedssystemer udfordrer interprofessionelle samarbejdspraksisser. Tidsskrift for Arbejdsliv, 20(3 SE-Artikler). https://doi. org/10.7146/tfa.v20i3.110813

Badham, R. (2005). Technology and the transformation of work. In Acroyd, Batt, \& Tolbert (Eds.), The Oxford Handbook of Work and Organizations (pp. 115-137). Oxford University Press.

Bertelsen, P. (2007). Vil elektroniske patientjournaler overflødiggøre lægesekretærer på de danske sygehuse? Tidsskrift for Arbejdsliv, 9(3), 28-43.

Ehn, P., Nilsson, E. M., Topgaard, R., Adler, M., Björgvinsson, E., Book, K., Emilson, A., Hillgren, P.-A., Hobye, M., \& Krona, M. (2014). Making Futures : Marginal Notes on Innovation, Design, and Democracy. The MIT Press.

Grosen, S. L. (2009). IT, arbejde og køn $i$ anvendelse: samproduktion $i$ det kvindedominerede admini- for, at teknologi bliver en del af dagsordenen for både nationalt og lokalt samarbejde mellem parterne og ikke mindst at kvalificering af inddragelsen af de ansatte styrkes, til alles fordel. Forskere, og også konsulenter, kan udvikle metoder og forløb, hvorigennem de ansatte på én gang får viden om de ny teknologier eller forandrede teknologianvendelser, der overvejes og, ikke mindst, hjælper til at bringe den konkrete erfaring de ansatte har med arbejdet i spil i forhold til disse. Det handler om at sætte viden om teknologiers muligheder i spil sammen med viden om arbejdets daglige praksis og tage sig tid til at gå ned i detaljen og stille spørgsmål om, hvad der mon kunne tænkes at ske i forhold til netop denne daglige praksis, når teknologi sættes i spil på nye måder.

Så bare kom i gang: Sørg for at teknologi for alvor bliver et inddragelses- og samarbejdsspørgsmål. Brug de ansattes fantasi - og kvalificér den! strative arbejde. Institut for Miljø, Samfund og Rumlig Forandring, Roskilde Universitet. Grosen, S. L. (2013). Standardisering: Nye udfordringer til den faglige identitet. Tidsskrift for Arbejdsliv, 15(4), 9-26.

Grosen, S. L., \& Hansen, A. M. (2021). Sensor-floors - Changing Work and Values in Care for Frail Older Persons. Science, Technology \& Human Values, 1.

Grosen, S. L., Kamp, A., \& Hansen, A. M. (2021). Arbejde og teknologi. In A. M. Hansen, A. S. Jakobsen, B. S. Nielsen, \& K. T. Nielsen (Eds.), Arbejdslivet $i$ kritisk perspektiv-problemstillinger og tendenser $i$ arbejdslivet. Frydenlund.

Halford, S., Obstfelder, A., \& Lotherington, A.-T. (2010). Changing the record: the inter-professional, subjective and embodied effects of electronic patient records. New Technology, Work and Employment, 25(3), 210-222. https:// doi.org/10.1111/j.1468-005X.2010.00249.x 
Hansen, A. M., \& Grosen, S. L. (2019). Transforming bodywork in eldercare with wash-anddry toilets. Nordic Journal of Working Life Studies.

Jasanoff, S. (2015). Imagined and Invented Worlds. In S. Jasanoff \& S.-H. Kim (Eds.), Dreamscapes of Modernity, Sociotechnical Imaginaries and the Fabrication of Power (1st ed., pp. 321-341). The University of Chicago Press.

Jasanoff, S., \& Kim, S.-H. (2015). Dreamscapes of Modernity, Sociotechnical Imaginaries and the Fabrication of Power (S.-H. Jasanoff, Sheila; Kim (ed.); 1st ed.). University of Chicago Press.

Justesen, L., \& Plesner, U. (2018). Fra skøn til algoritme: Digitaliseringsklar lovgivning og automatisering af administrativ sagsbehandling. Tidsskrift for Arbejdsliv, 20(3 SE-Artikler). https://doi.org/10.7146/tfa.v20i3.110811

Mills, C. W., \& Gitlin, T. (2000). The Sociological Imagination. Oxford University Press USA - OSO.

Negt, O. (2019). Dannelse og demokrati. (1. udgave.). Frydenlund.

Nielsen, K. T. (2001). Udviklingen i den skandinaviske arbejdslivstradition: nogle eftertanker. Tidsskrift for Arbejdsliv, 3(2), 9-18. http://www. nyt-om-arbejdsliv.dk/artikel.aspx?itemID $=62$

Olsén, P., Nielsen, B. S., \& Nielsen, K. A. (2003). Demokrati og boeredygtighed: social fantasi og samfundsmoessig rigdomsproduktion (K. Aagaard Nielsen, B. S. Nielsen, \& P. Olsén (eds.); 1. udgave.). Roskilde Universitetsforlag.
Orlikowski, W. J. (2000). Using Technology and Constituting Structures: A Practice Lens for Studying Technology in Organizations. Organization Science, 11(4), 404-428. http://www. jstor.org/stable/2640412

Oudshoorn, N. (2008). Diagnosis at a distance: the invisible work of patients and healthcare professionals in cardiac telemonitoring technology. Sociology of Health \& Illness, 30(2), 272-288. https://doi.org/10.1111/j.14679566.2007.01032.x

Robertson, T., \& Simonsen, J. (2013). Participatory Design: an introduction. In J. Simonsen $\&$ T. Robertson (Eds.), Routledge international handbook of participatory design (pp. 1-18). Routledge. http://rub.ruc.dk/soeg/kviksoeg/?query=9780415694407

Thomsen, R. (2016). Administrativt arbejde - er det noget saerligt?, et praksisperspektiv på arbejde og forandringer. Center for Arbejdslivsforskning, Institut for Mennesker og Teknologi, Roskilde Universitet.

Wilson, M. (2002). Making nursing visible? Gender, technology and the care plan as script. Information Technology \& People, 15(2), 139. http://proquest.umi.com/ pqdweb? did $=208466341 \& \mathrm{Fmt}=7 \&$ clien$\mathrm{tId}=23677 \& \mathrm{RQT}=309 \& \mathrm{VName}=\mathrm{PQD}$

Sidsel Lond Grosen, Lektor, ph.d.,

Center for Arbejdslivsforskning, Institut for Mennesker og teknologi, RUC

e-mail: sgrosen@ruc.dk 